\title{
Mission as 'saving' abandoned infants in Johannesburg inner city: An evaluation of the Door of Hope Mission
}

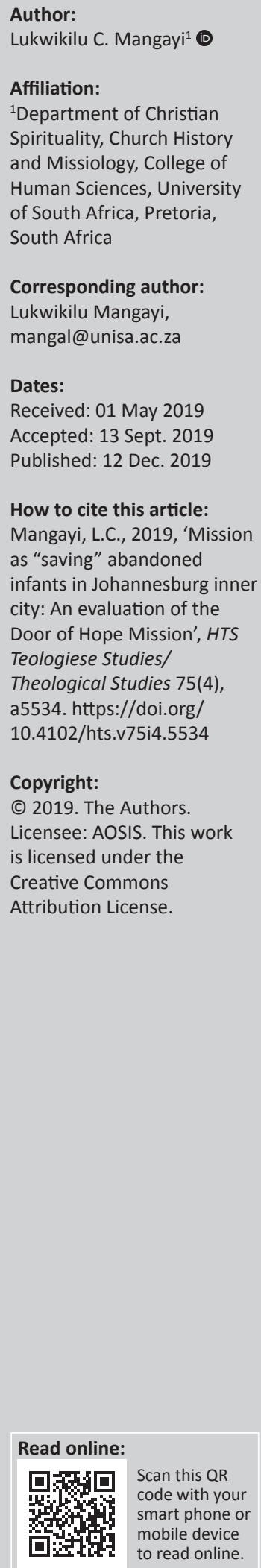

In this study, I position the Door of Hope $(\mathrm{DoH})$, an organisation which attempts to work with abandoned and orphaned children, as a faith-based organisation and attempt to determine its effectiveness in relation to missio Dei [the mission of God]. This evaluation focussed on the four different 'mission orientations' that a religious community could have in society. Insights gained through this scrutiny of DoH highlight the notion that faith-based organisations in areas such as the inner city of Johannesburg in South Africa can genuinely embrace God's mission as co-workers in God's mission to realise a transformed reality symbolised by shalom or collective well-being of all of creation, in particular, for the most vulnerable citizens of Johannesburg inner city, such as infants and young women at risk.

Keywords: abandoned infants; Door of Hope Mission; Hillbrow-Berea; Johannesburg Inner City; mission.

\section{Introduction}

\section{In Johannesburg,South Africa (Mosselson 2017):}

\begin{abstract}
Life in the inner-city represents a [of] variety things -it is a site of possibilities, opportunities, social advancement and transformation, but is simultaneously a place of hardship, endurance, marginalisation and resignation. It is therefore, a mirror of the post-apartheid situation, in which progress, new experiences and change sit alongside old and new forms of dispossession, marginalisation, struggle and inequality. (p. 164)
\end{abstract}

Victims of this dispossession include the most vulnerable such as abandoned infants who are left to die on the streets, as is the case in Berea, near Hillbrow (Noble, Wright \& Cluver 2006). Abandonment of infants is contrary to the African notion of solidarity captured in the words of this adage: ' $[a]$ child in the womb belongs to the mother but once born, that child belongs to the community'. ${ }^{1}$ Berea Baptist Mission Church (BBMC) near Hillbrow in Johannesburg gives expression to this adage through its Door of Hope $(\mathrm{DoH})$ mission, which focuses on saving and caring of abandoned infants. DoH is a faith-based organisation registered with the South African government as a non-profit organisation (NPO) and a public benefit organisation (PBO) working for the welfare of abandoned and orphaned children. BBMC, through $\mathrm{DoH}$, sees this abandonment of infants as a mission opportunity, which consists of saving the infants from the dangers associated with abandonment, providing psychosocial and spiritual care including shelter, care and dedication service (i.e. when children are brought to church to be prayed for) and facilitating adoption placement into stable Christian families locally and abroad. In brief, DoH is about 'loving their vulnerable neighbours' - in this case, abandoned infants - 'as they love themselves' (see Mt 22:39) in a holistic manner. Thus, this local church's ministry is an asset in mission and has increasingly become a beacon of hope in a decaying inner-city neighbourhood. It has also literally become a catalyst towards change in the welfare of abandoned infants.

Furthermore, it is important to note that the abandonment of infants must not be seen in isolation to multidimensional challenges present in Johannesburg, particularly inner-city neighbourhoods, such as Hillbrow, Berea and Yeoville. Various urban challenges and transitions are noticeable in these neighbourhoods in terms of societal fractures and urban poverty, especially as it affects the most vulnerable such as women, young children and infants with accompanying injustices or exclusion. These challenges, compounded by socio-economic, psychosocial, demographic and spiritual issues, as well as urban decay, make up the reality of most contemporary inner-city contexts in South Africa. These challenging issues, as with most faith-based organisations in the inner city, are in 'the face' of $\mathrm{BBMC}$ and its ministries on a daily basis.

1.This is a common idiom of the Yaka ethnic group in the Democratic Republic of the Congo.

Note: Faith-Based Organisations, sub-edited by Nadine Bouwers du Toit (Stellenbosch University), Vhumani Magezi (North-West University) and Elisabet le Roux (Stellenbosch University). 
Thus, in this article I contend that faith-based organisations such as DoH present in an area like this cannot genuinely embrace God's mission without 'getting their hands dirty' in attempting to co-work with God who works towards 'making everything new' (see Rv 21:5). This is a transformed reality symbolised by shalom or collective well-being of all creation including neighbourhood regeneration.

Hence, in this study, I evaluate DoH as a faith-based organisation to determine its effectiveness in relation to missio Dei [the mission of God]. For this evaluation, I use insights presented by Roozen, McKinney and Carroll (1984:87) concerning the four different 'mission orientations' that a religious community could have in society.

Central to this evaluation is exploring the question, 'based on DoH model, what role(s) could the church and its ministry play to contribute towards missio Dei in Johannesburg inner city?' This question underscores one of the important expectations of a local church in mission with God, which points to Christian witness starting right where the church is. This witness revolves in particular around abandoned infants in Hillbrow-Berea area in the case of DoH. Given their proximity and similarity in context, these two inner-city neighbourhoods in Johannesburg provide us with the context of this study.

\section{Contextual insights}

I relied on insights and inputs from the literature and from documents in the public domain posted on the website of DoH. These insights are supplemented by personal observations as I have experiential knowledge of the neighbourhood.

\section{Hillbrow-Berea}

Socio-economic, historic and spatial development of Hillbrow-Berea will be discussed in this section to provide a picture of critical issues relative to disintegration of these neighbourhoods. Then, in relation to missio Dei, I will discuss the role of faith-based organisations in saving the lives of some of the most vulnerable members of disintegrated communities, such as infants.

The disintegration of Hillbrow and Berea is apparent in every way in post-apartheid South Africa.

\section{Mosselson (2017) explains that:}

After the end of apartheid, inner-city neighbourhoods such as Hillbrow and Berea were in severe states of decay and anomie, with extremely high levels of crime, broken infrastructure and tense social relations. (p. 15)

Morris (1996:670) also highlights how the physical decline and racial stereotyping of new residents accompanied this rapid 'greying' of the inner city. Nonetheless, these two suburbs, including Yeoville, are the most demographically diverse neighbourhoods in the inner city of Johannesburg.
With particular reference to Hillbrow, Matshedisho and Wafer (2015) elucidate:

It is [now] densely populated by migrants from the African continent since the early 1990s. Previously it was occupied by European migrants particularly from the United Kingdom, Germany and Eastern Europe. (p. 67; see also Morris 1999:670)

Personal observations attest to the fact that the trajectory in Berea and Yeoville is similar to that of Hillbrow. ${ }^{2}$

Furthermore, from functionality standpoint, it is difficult to demarcate boundaries between Hillbrow and Berea. As a result (Matshedisho \& Wafer 2015):

... [T] his seamless urban functional area is often referred to as Hillbrow-Berea in municipal policy and academic literature. It was common to the point of norm during the research process for residents to refer to Hillbrow even if they were technically referring to parts of Berea. (p. 69)

Thus, I concur with Matshedisho and Wafer (2015:69) based on personal ministry experiences on the ground that supports the notion that Hillbrow is not a simple neighbourhood to define - existing largely as a space of association, rather than an administrative boundary. Most people in this area have the same challenges.

\section{Socio-economic challenges in the Hillbrow-Berea-Yeoville area}

Hillbrow-Berea-Yeoville is the most diverse area around Johannesburg and, as previously stated, migrants from the African continent densely populate it. Crowds of people live in close proximity in confined spaces.

As a result, people are constantly 'shifting'. Matshedisho and Wafer (2015:74) explain 'shifting' is the regular and frequent changing of accommodation. It simply means that people seldom stay in one place indefinitely, shifting as circumstances change.

This shifting has implications for local institutions and organisations, such as churches where members' affiliation tends to be temporal as they may move to another area. Desperation for shelter is apparent and people crowd in small spaces. Every month end, as explained further by Matshedisho and Wafer (2015:75), '... small crowds of people gather at known street corners where handwritten signs offer everything from beds to share to balconies for rent'. There is also the issue of homelessness. Matshedisho (2015:144) states, '... moving through Hillbrow [-Berea] one observes groups and individuals who are homeless'. 'Many of the homeless people in Hillbrow are from different parts of South Africa, coming from rural parts of the country to the city centres'.

These issues, in addition to crime and theft, prostitution and decay and collapse of physical infrastructure, make HillbrowBerea as hazardous places to live in Johannesburg. Yet, it is in many ways where migrants, including South Africans from 2.l lived in Berea in 1990-1992 and ever since remained closely associated with these three neighbourhoods through ministry and social. 
rural areas, have made their home - both for their own survival and that of their families and relatives. Residents of Hillbrow-Berea live constantly in insecurity and instability marked by 'fear and anxiety of mugging and grievous crimes that occur from sunset until dawn ... police bribes, brutality and profiling' (Matshediso \& Wafer 2015:83). The gruesome reality described by Matshediso and Wafer is known to all who live in or frequent the area. The regeneration or renewal project of Hillbrow-Berea is, therefore, of utmost importance.

\section{Regeneration of Hillbrow-Berea: Issues and challenges}

I concur with Matshedisho and Wafer (2015:83) that '... [t]oday's Hillbrow [-Berea] is of course different from the place of the past in terms of infrastructure, governmentality, racial composition and materiality'.

For Mosselson (2017:147), this is caused by '... extensive capital flight and residential change in the 1980s and 1990s which left the inner-city in a severe state of disrepair and anomie'. Now, the black population is the predominant race. Yet, as Matshedisho and Wafer (2015) put it:

... [T] he racial 'blackness' of Hillbrow [-Berea] that constitutes the narrative hides the diversity of origin, language, culture, socio-economic status, legal status, age, gender, sexuality, purpose of migration and religious backgrounds. (p. 83)

This dense demographic diversity contributes, in my view, to the degeneration of these neighbourhoods.

Furthermore, there are various reasons for the multifaceted degeneration of the Hillbrow-Berea. Mosselson (2017) states that:

... [T] he area came to be characterised by slumlords, derelict buildings, many of which were disconnected from water and electricity services and severely overcrowded, high rates of violence and crime, a prevalent drug trade and general dysfunction and decay. (p. 147)

The regeneration and development project has to overcome all these challenges if it has to succeed.

Bremner (2000:190) highlights the fact that the recent and ongoing history of development in the Johannesburg inner city tells about the transformation, reformulation and reimagining of an urban landscape.

From personal observation, I would argue that local government attempts at regeneration have not succeeded. This could be mainly because of the volatility and endemic and persistent nature of the various issues highlighted in the previous sections. One of these flawed attempts by government is eviction of people from illegally occupied buildings. According to the Centre on Housing Rights and Evictions (COHRE) (2005), these evictions have frequently been brutal, and scenes of people tossing onto the streets alongside their belongings are common (see Mosselson 2017:149). The latest eviction was conducted and led by the current Executive Mayor ${ }^{3}$ of the city, Herman Mashaba, on 20 October 2017 as part of his clean-up campaign, which also involves ridding the city of illegal immigrants. In addition to this more visible and violent form of eviction, there is the ongoing less overtly visible form, referred to earlier as 'shifting'.

For Murray (cited in Mosselson 2017:149), this indirect displacement has also been common as property costs and rentals have increased and many of the most vulnerable and in-need people have either been forced out of the area or moved into derelict properties on the periphery of the inner city. At the heart of this shifting is also what I call 'opportunistic exploitation' of the most vulnerable such as refugees and women with small children by property owners. Bremner (2000:186) sees this as linked to white flight from inner city to the suburbia which had been aided and abetted by landlords for economic interest and consequently contributing to decay and degeneration.

From the above discussion, I deduce that issues of poverty, informal housing, decay, neighbourhood degeneration, demographic challenges, informal economic activities, crime and violence, which are common in Hillbrow-Berea area, pose serious difficulties for regeneration agenda. The intricate correlation between these issues should thus not be taken lightly (COHRE 2005). An inclusive city, equality and shared experiences of urban citizenship thus remain elusive (Harrison et al. 2003, cited in Mosselson 2017:153). Yet, for many vulnerable and poor people, the Hillbrow-Berea, because of its volatility, informality and lack of traditional codes of conduct appears to be the only option regardless of the fact that people distaste many of the things and ills prevalent in this area. A resident of the area who participated in the empirical research conducted by Mosselson (2017:155) confirmed this, as she stated, 'I'm not staying in Hillbrow because I like drugs and crime - it's affordability' (Tenant 9, Lake Success, Hillbrow, 01 March 2013).

\section{Regeneration of Hillbrow-Berea: Steps taken by the local government}

Spatial changes in terms of demographics and economics were precipitated by various factors in Johannesburg. The greater Johannesburg Metropolitan Council Planning Document (1999b, cited in Bremner 2000:190), for example, highlights many factors such as decline of industrial base and economic strength, flight of corporate capital and burgeoning informal sector.

In response to the challenges described in the previous section, the city authorities and structures undertook some steps to address the plight of Johannesburg in general and inner city in particular. These responses focussed on reinventing the Johannesburg inner city. Bremner (2000:187) contends that the city and its strategic structures sought to develop a '... evolving set of local economic development 3.http://702.co.za/articles/277171/mayor-herman-mashaba-to-approach-thecourts-to-deport-undocumented-immigrants. 
initiatives to reinvent, re-imagine and re-market the Johannesburg inner city'. Furthermore, Bremner (2000:187-191) highlights two of these responses: (1) Gateway to Africa and (2) Golden Heartbeat. It is beyond the scope of this study to delve into the discourse relative to the re-invention of Johannesburg inner city as Bremner's contribution does that. In brief, each of these responses aimed at different things. The 'Gateway to Africa' notion aimed at provision of social services and goods to the promotion of local economic growth and the reversal of economic decline, whereas the 'Golden Heartbeat' notion aimed at building an inclusive city for residents, workers, tourists, entrepreneurs and learners.

Current reality on the ground suggests that the local government's interventions towards making Johannesburg the financial and commercial hub of sub-Saharan Africa and an inclusive city are hindered on many fronts. The flight of corporate capital accompanied with socio-economic instability of countries in the Southern African Development Community and other regions of Africa in particular made Johannesburg inner city to become a haven for informal businesses. People from rural South Africa as well as from other regions of Africa are everywhere in the city. Johannesburg's past history of the 'city of gold and opportunities' and its infrastructural assets are among the pull factors in this exodus to the city. Poor African young people, including young adults in particular, have come to Johannesburg in the hope of improving their situation.

Unfortunately, the dream of realising sustainable jobs and 'the good life' remain elusive for many. The situation is worsening also with food insecurity (Crush, Frayne \& Pendleton 2012:276). Decent housing is beyond their reach, many of them remain also excluded from social security and social welfare programmes of government (see Goebel, Dodson \& Hill 2010:373-374). Out of desperation, some of these people resort to illicit means, such as stealing, prostitution and selling drugs to earn a living. Thus, young lives are wasted. Young women trapped in this situation are victims of unwanted pregnancy and then end up with babies without shelter and security. These babies are abandoned in parks, on the street corners and in public places.

Some of these babies are 'dumped' at the DoH to afford them for a chance to better life. Against the contextual background described above, the DoH initiated an action of hope.

\section{Door of Hope Organisation}

\section{A personal encounter with abandonment of an infant}

One Friday late afternoon in August 2017, I was at the $\mathrm{BBMC}^{4}$ office for a meeting with leaders of the church when we heard the crying of a little infant. We went out and found an infant wrapped in a blanket and left on the stoep of the building. This nameless and motherless male infant abandoned alone on the stoep of the church building was the 4.BBMC stands for Berea Baptist Mission Church. most vulnerable and defenceless of victims of dispossession and marginalisation amongst the poorest of poor people imaginable in the Johannesburg inner city. He was disowned, homeless, abandoned and defenceless, and had no chance for future unless some charity and compassion were given to him.

Abandonment of infants such as this one is a daily reality at BBMC. DoH ${ }^{5}$ elucidates:

Abandonment of infants in South Africa is, unfortunately, a common occurrence. Many of these children are left to die, or simply abandoned, in dustbins, open fields, public toilets or on train tracks.

Research conducted by Dee Blackie, a consultant to the National Adoption Coalition of South Africa from March 2013 to February 2014, confirms this reality. Blackie's (2014) research uncovers that:

... [C] hild Welfare SA estimated that more than 3500 babies were abandoned in SA in 2010. There are no current statistics detailing the number of children who are abandoned in South Africa on an annual basis, but most child protection organizations believe that the numbers have increased significantly over the past decade. (p. 1)

Since its inception in 1999, the DoH responds to this crisis almost daily.

\section{The mission of Door of Hope}

The DoH is situated in Berea-Hillbrow and its immediate context is the one described in the previous section. According to the information available on its website (http:// doorofhope.co.za/our-work/), the mission of $\mathrm{DoH}$ is fourfold and exists on a continuum of care interventions: (1) saving abandoned babies, (2) bringing children home, (3) building people of character and (4) bridging a better world. This ministry regarding saving abandoned babies started in 1999 under the leadership of Pastor Cheryl Allen. The church made a hole in the wall and a 'Baby Box' which allows mothers anonymously to leave their babies any day or night for the church to take care of them. Ever since, babies have been brought in by their mothers, police, community members, hospitals or clinics.

Towards realising their goal concerning bringing children home, three baby houses have been established to date. In these houses, the children find a community of moms and dads, aunts and uncles, cousins, grannies and grandpas who love, care and cherish them until such time they are adopted, reunited with extended family, placed in specialised homes or join the DoH village family.

In relation to their mission, $\mathrm{DoH}$ states on the webpage that their ultimate goal is to develop the children in the village family in five key areas: (1) in terms of character they must raise the children to be people of love, joy, peace, patience, kindness, goodness, faithfulness, gentleness and self-control; 5.Viewed 30 April 2018 , from http://doorofhope.co.za/stories/. 
(2) in terms of competence they must develop the children with the necessary skills to not only survive but also to thrive in the world; (3) in terms of calling they must equip them and help them to discern and live out their unique gifting and purpose in the world; (4) in terms of confidence, they must instil in them a healthy belief in themselves, their capabilities and potential, and ultimately a faith in God and what he can accomplish in and through their lives; and finally (5) in terms of courage they must encourage them to live lives of bravery and valour.

The DoH continues to deliver on its mission and has realised positive outcomes for over 1500 babies that have come through its doors since its inception. The story of Georgina captures the integrated multifaceted and holistic care given to each child who comes through the DoH. Pastor Cheryl Allen, founder of DoH mission, narrates (see http:// doorofhope.co.za/our-work/):

Georgina was our first child to arrive at Door of Hope in August 1999. She was 14 months old and was suffering from neglect and malnourishment. Her biological mom loved Georgina enough to see she couldn't cope and brought her to us. Pastor Cheryl and the church leaders were very concerned for Georgina as she had a protruding forehead and was not speaking at all. They thought she might be brain damaged. Door of Hope gave her lots of love, care and good nutrition. Most important of all, they prayed for her. God led a wonderful couple to adopt Georgina and take her back to their home in the United States of America.

In first grade, Georgina was identified as an academically gifted student. These gifted students are given extra attention and counselling to keep them more fully engaged and able to accelerate beyond their peer group. She achieved high marks during each of her seven years of public school.

She graduated from High School in 2016 and today she is a bright college student with many achievements behind her and more to come.

As gifted as she is academically, her real passion is music. She has been able to play the violin and the piano through private classes. She has also taught herself to play the guitar a little. However, singing is what she has most enjoyed and excelled in. She sings all through the day and night. Sometimes she sings in church. She has sung to audiences ranging in size from a few dozen to several thousand. She spent six years in the worldfamous Virginia Children's Choir. They taught her not only to perform, but to sight read music. One year, the Choir toured in England and France. Georgina had a solo role in the tour and in England; she performed at the Royal Albert Hall with the London Symphony Orchestra.

Her adoptive father wrote to the DoH some years back with these words:

The most precious memory we have is the day I had the privilege of baptizing [Georgina]. We are indeed proud parents watching our 'little girl' grow up to love and serve the Lord Jesus Christ. I enjoy sharing of her achievements in order to encourage the staff, volunteers, supporters, and children (both current residents and those that have gone to be with their forever families). The children in the Door of Hope are being given love, but they are also being given hope. First of all they receive the Hope of eternal life in Jesus Christ. Through this love from the staff and volunteers in the Baby House and then with their forever families, they are given a place of privilege and an opportunity to grow to their full, God-given potential. Only God knows what type of leaders are being prepared as life paths are changed by the touch of the Door of Hope Children's Mission.

\section{Pastor Cheryl Allen continues:}

In July 2016, Georgina made history again by being the first Door of Hope child to return as a volunteer. She spent a few weeks with us helping to love and care for the babies in our homes. We are super proud of you Georgina. You have grown to be a lovely young lady. You shine as a symbol of hope to all abandoned and orphaned children. We pray God continues to do great things in and through you for the glory of His name. (see Is 61:3)

What seems clear from the narratives of $\mathrm{DoH}$ is that their programme of intervention goes beyond shelter and child protection to include psychosocial and spiritual support and nurturing. Results and impacts of the programme, including that of Christian witness, are multifaceted and multidimensional as captured in the story of Georgina. What is also obvious is the manner in which care, love, protection, Christian witness and evangelism intertwine and flow ceaselessly in a continuum from caregivers in the houses to adoptive parents who become the 'forever families' of these children. Of particular importance is the fact that Christian lifestyle, evangelism and discipleship are weaved together with welfare and charity in ceaseless flow till these children become adults and are in a position to live on their own. The participation of DoH in the missio Dei could be traced in forms and shapes through their interventions as focused in hope. Later, I will evaluate these interventions to ascertain DoH's worldview and mission orientations in relation to missio Dei.

\section{Mission, development and life as related to the DoH}

God's mission is intrinsically life giving (see Jn 10:10). DoH sees itself in mission with God as it embraces 'God's initiative rooted in God's purposes to restore and heal creation' (Guder 1998:4) as far as the welfare of babies is concerned. In essence, the DoH's mission work is 'practicing forgiveness and solidarity with the poor'. Hence, the aim or ultimate goal of expressed faith in most religions is welfare and development of all people in society. In relation to development, Ter Haar (2011:5) states that:

\footnotetext{
Religion and development have more in common than is normally apparent. At the foundation, both are visions of how the world may be transformed. From a religious perspective, the transformation of individuals, or inner transformation, is deemed a necessary condition for transforming society and the world as a whole. From the professional development [including welfare] perspective, on the other hand, it is primarily the external environment, or the arrangements made for the provision of material resources, that constitutes the site of transformation.
}

Thus, when a Christian or church development perspective is integrated within the professional development perspective, 
it results in '... integral development - a conceptual area where these two fields merge' (Ter Haar 2011:5, see also Mangayi 2016:105). This integral development and welfare are applied by the DoH in relation to abandoned babies. Of course, faith-based groups often overlap with secular nongovernmental, national and international organisations in their respective work to advance social and economic development (Marshall \& Van Saanen 2007:1).

In relation to the church and religious institutions, the key element for effective inter-sectoral partnerships is the social capital, which these institutions bring to the partnership. Such capital refers essentially "... to the importance of "social partnerships" and "social networks" as the building blocks of society' (Swart 2012:75). One of DoH's strengths is based upon drawing from the social capital available to it through international partnerships the world over with church networks and individual Christians who volunteer their services and resources 'doing good' (Ac 10:38) as Jesus did, so that these children from the developing world can have good prospects for life.

In the same vein, as Ter Haar (2011:5) points out, ' $\ldots[F]$ or most people in the developing world, religion is part of "the vision of the good life"'. Therefore, with reference to South Africa, Swart (2010:325), for instance, states that, ' ... churches and other faith-based organisations should be regarded as most strategic in contributing to the challenge of moral regeneration and reaching the South African population at large'. In relation to research conducted in communities in the Western Cape, Swart (2010:326) perceives churches as offering a stock of social capital for promoting social development in that province. In my view, DoH does just that in terms of promoting social development in Gauteng province as the work of the DoH overlaps with that of other organisations in the province. This overlapping notion resonates with research elsewhere conducted by Marshall and Van Saanen (2007:1), which states that, '... faith-based groups often overlapped with secular nongovernmental, national, and international organisations in their respective work to advance social and economic development'.

However, with reference to South Africa, Swart (2010:27) also recognises some limitations and suggests that the religious sector will only gain credibility as one of the significant drivers of social change if '.. it becomes a rigorous exponent itself of the social development paradigm on the level of actual implementation and empowerment'. Swart's suggestion is a call which amounts to some sort of 'reformation' given the fact that, as Ter Haar (2011:5) writes, ' ... [m] any secular people find it hard to think about religion in positive terms, as something that can help build human societies rather than contribute to their destruction'. This perception of Mangayi (2016:110), '... about religious or faith-based organisations will only be changed if they become instruments of hope and restoration in the communities'. $\mathrm{DoH}$ is a positive example of a faith-based organisation, which is the embodiment of hope and restoration in the communities they serve. DoH is indeed a Christ-incarnate organisation in Johannesburg inner city as it motivates the church and individual Christians, through its work, to be fully humans again.

In agreement with the concept of God's incarnation, the DoH with its pool of workers and volunteers declares through it ministry that the Christian life is about '... becoming fully humans' (De Gruchy 1986:75). In this sense, one is not interested in a Christ who only offers eternal life, but in a Christ who recognises and sweats and bleeds with the victims of oppression (Bosch 1991:513) and who takes the initiative to 'release' the victims of various forms of oppression (Bosch 1991:513; cf. Lk 16:1-2,4:18). The incarnation of Christ thus models to us what humanity should be concerned with. Christ shows us to be God's image on earth, being fully human, and how - through being fully human - we can actually make God's presence known. This is at the core of missio Dei. I am of the view that the DoH attempts to make God's presence known in practical ways in relation to abandoned or orphaned infants. DoH participates in God's mission as co-workers to realise a transformed reality symbolised by shalom or collective well-being of all of creation, in particular for the most vulnerable citizens of Johannesburg inner city such as infants and young women at risk.

An analytical evaluation of $\mathrm{DoH}$ as an agent of mission is therefore necessary, which is discussed in the next section.

\section{An analytical evaluation of $\mathrm{DoH}$}

To conduct an analytical evaluation, I used the insights presented by Roozen et al. (1984:87) concerning the four different 'mission orientations' in order to appraise a ministry such as that of the DoH. Kritzinger (2013) elaborates the following about this model:

They (i.e. Roozen, McKinney and Caroll) look at how the worldview of a community (the question whether it is thisworldly or other-worldly in orientation) combines with the boundary-making activities of that community (the question whether they are membership-centred or publicly proactive) to produce four mission orientations, which they call a civic, sanctuary, activist and evangelistic orientation. (p. 37)

The four mission orientations, boundary-making activities of that community (the question whether they are membershipcentred or publicly proactive), including worldview, are presented in Table 1.

A Christian community that is this-worldly in its worldview believes that God's will should be done on earth by Christians here and now. If this community would combine their thisworldly worldview with boundary-making practices that are membership-centred, this means they would place greater emphasis on building the identity of their existing members, doing what they can to keep their members happy and together. In order to combine those two dimensions, they would allow members to make up their own minds about political matters, they would strengthen traditional cultural and social values, and they would try to minimise conflict between members and in society. Roozen et al. (1984) call this 
TABLE 1: A 'map' for understanding the community engagement of Christian congregations.

\begin{tabular}{|c|c|c|}
\hline \multirow[t]{2}{*}{ Worldview } & \multicolumn{2}{|r|}{ Mission orientation } \\
\hline & Membership-centred & Publicly proactive \\
\hline This-worldly & $\begin{array}{l}\text { Civic orientation } \\
\text { - Affirm existing social structures } \\
\text { - Indivs civil harmony and avoidance of conflict }\end{array}$ & $\begin{array}{l}\text { Activist orientation } \\
\text { - Stress justice and a critical posture to existing social structures } \\
\text { - Openness to involvement of members and congregation in social action } \\
\text { - Openness to confrontation and conflict }\end{array}$ \\
\hline Other-worldly & $\begin{array}{l}\text { Sanctuary orientation } \\
\text { - Refuge from this world } \\
\text { - Tradition and doctrine } \\
\text { - Opposition to congregational involvement in social change } \\
\text { Patriotism and adherence to civil law }\end{array}$ & $\begin{array}{l}\text { Evangelistic orientation } \\
\text { - Personal witnessing } \\
\text { - Seek conversion of everyone to the 'one true faith' } \\
\text { Strong openness to the Holy Spirit }\end{array}$ \\
\hline
\end{tabular}

Source: Kritzinger, J.N.J., 2013, Integrated theological praxis, 'Capstone' module, University of South Africa, Pretoria.

a civic orientation. However, if their this-worldly worldview is combined with boundary-making practices that are publicly proactive, they would allow members to work for social justice and develop a critical posture towards existing social structures, openness to involvement of members and congregations in social action as well as openness to confrontation and conflict. Roozen et al. (1984) call this orientation an activist orientation.

In contrast to the aforementioned, a Christian community that is other-worldy in its worldview believes that God's will should be done only in the world to come. If this community combines their other-worldly worldview with boundarymaking practices that are membership-centred, this means that they would place greater emphasis on taking refuge from this world, upholding their tradition and doctrine, mounting pressure on congregational involvement in social change while persuading their members towards patriotism and adherence to civil law. Roozen et al. (1984) identify this as a sanctuary orientation. However, if their other-worldly worldview was combined with boundary-making practices that are publicly proactive, they would allow members to do personal witnessing, seek conversion of everyone to the 'one true faith' and have strong openness to the Holy Spirit. Rozen et al. (1984) call this an evangelistic orientation.

A scrutiny of the DoH mission, using insights from Roozen et al. (1984:87), reveals the following: based on the information in the public domain provided by the $\mathrm{DoH}$ leadership, I could establish that this ministry's focus is on the one hand this-worldly in that it interacts with the community on an ongoing basis. Within this-worldly worldview, its mission focus includes both elements of civic orientation (i.e. it encourages members of churches in their network locally, nationally and internationally to do community outreach which hints at civic orientation). The mission focus is also publicly proactive in that, through its integrated ministry model, it stresses building people of character and bridging a better world and openness to involvement of its members and associates in faith projects, which suggests activist orientation. The motivation for saving these abandoned and orphaned babies goes beyond welfare and child protection to include psychosocial and spiritual empowerment and building society in a better way. This is apparent in the story of Georgina told earlier.

However, in the mix of these two focusses (memberscentred and publicly proactive), this ministry also has an other-worldly perspective through its lifestyle evangelistic orientation as it is expected to be lived out initially by staff and caregivers and later on by adoptive parents in their forever families. There is an anticipated expectation that in time the children will receive the Lord Jesus in their lives. The adoptive parents of Georgina capture this clearly, when they stated, '[f]irst of all they receive the Hope of eternal life in Jesus Christ'. The hope of eternal life in Jesus Christ points to the other-worldly perspective. Of importance is the fact that at the age these children are received in the houses and given to adoption, caregivers and parents cannot coerce the children to believe in the Lord Jesus. They must live out their faith as model believers to these children. This lifestyle evangelism is also a basis for the selection and recruitment of staff and one of the conditions for consideration of adoptive parents.

\section{The DoH in light of the missio Dei}

The brief evaluation in the previous sections reveals that DoH combines the 'this-worldly' and 'other-worldly' worldviews. In its 'this-worldly' worldview, its mission orientations include civic and activist elements and in its 'other-worldly' worldview, its mission orientation is evangelistic. I take note of the following from this evaluation: (1) it is clear that the $\mathrm{DoH}$ goes against 'privatised religion' or the sanctuary orientation; (2) it affirms other social structures such as the Adoption Coalition networks and Welfare organisations as well as Home Affairs that work in the continuum of care for the children by forging partnerships with them in order to maximise the services offered to the children entrusted to them ${ }^{6} ;(3)$ it goes the extra mile to mobilise assets and gifts within the church and outside in the society to the benefit of these most vulnerable children ${ }^{7}$; and (4) it points the children to connect with Jesus for eternal security ${ }^{8}$.

In general, I realise that $\mathrm{DoH}$, as a ministry of BBMC, sees itself as sent to Johannesburg in witness to God, as Jesus Christ did, for saving abandoned and orphan infants as an act of love. Flett (2014), for example, states that:

As Jesus Christ's own coming as a witness to the Father is God living his own proper life, so the church's own coming into the world under the impulsion of the Spirit to witness to the love of God in Christ. (p. 75)

6.http://doorofhope.co.za/our-work.

7.Georgina story narrated early affirms this point.

8.Georgina's holistic development and progress is a testimony 
Under the impulsion of the Spirit, DoH was initiated and it keeps moving on to witness to the love of God in Christ by practically loving the most vulnerable citizens of Johannesburg inner city, that is, abandoned and orphaned infants.

Furthermore, DoH attempts to give meaning to the missio Dei, which equates 'sending' with the being of God in places of despair marked by dehumanisation and poverty such as Hillbrow-Berea. DoH has grasped, in my view, that God is missionary. In other words, '[ $h]$ e sends, first, his Son and Spirit, and then his church, but then also creation itself' (Flett 2014:75).

Berea Baptist Mission Church, through the DoH, has responded to the calling to be sent and participates in missio Dei that includes many facets. Their participation portrays simultaneously church with others in charity as the love of God compels us (Lk 10:33-35 model) and standing with the poor and weak members of society to facilitate the realisation of freedom (Is 61:1-3 and Lk 4:18 model). DoH is also involved in life giving in this life and facilitates connections with eternal life in Jesus (Jn 3:16 model).

However, based on the information available to me, DoH appears to be weak with regard to advocacy and avoids confrontation with systems of power that breed the conditions which result in the kind of vulnerability and poverty that would lead young women in poverty to opt for the abandonment of their children. I contend that their mission orientation will be further strengthened if they rise to fight systemic evil, which breeds death, instead of life in Johannesburg inner city. In brief, I argue for an activist orientation to their mission in the city while acknowledging that it is not easy for an organisation such as DoH to embrace this orientation without considerable change. They could also imagine strategies, which could give hope to the young mothers trapped in poverty so that they would opt for keeping and caring for their babies instead of abandoning them. This matter could be one of the issues for further evaluation and research.

\section{Conclusion}

Abandonment of infants, particularly in inner-city neighbourhoods such as Hillbrow and Berea in Johannesburg, represents one of South Africa's societal fractures associated with urban poverty and results in the worse form of exclusion. This article, based on the scrutiny of $\mathrm{DoH}$, highlights that faith-based organisations in areas such as these can genuinely embrace God's mission by co-working with God to realise a transformed reality symbolised by shalom or collective well-being of all of creation, in particular for the most vulnerable citizens of Johannesburg inner city such as infants and young women at risk.

Finally, the contribution made by this study underscores the missiological importance that a local church, in partnership with the missional God in inner city areas such as Johannesburg, should be poised to carry its Christian witness. This can be achieved by addressing real needs that present themselves at their doorsteps, such as in the case of BBMC through its DoH mission.

\section{Acknowledgements Competing interests}

The author has declared that no competing interest exist.

\section{Author(s) contributions}

I declare that I am the sole author of this research article.

\section{Ethical considerations}

This article followed all ethical standards for research without direct contact with human or animal subjects.

\section{Funding information}

This research received no specific grant from any funding agency in the public, commercial, or not-for-profit sectors.

\section{Data availability statement}

Data sharing is not applicable to this article as no new data were created or analysed in this study.

\section{Disclaimer}

The views and opinions expressed in this article are those of the authors and do not necessarily reflect the official policy or position of any affiliated agency of the authors.

\section{References}

Allen, C., 2018, Door of Hope stories, viewed 30 April 2018, from http://doorofhope. co.za/stories/.

Blackie, D., 2014, Child abandonment and adoption in the context of African ancestra beliefs in contemporary urban South Africa, Fact Sheet on Child Abandonment Research in South Africa, National Adoption Coalition South Africa, Johannesburg.

Bosch, D., 1991, Transforming mission: Paradigm shift in theology and mission, Orbis Books, Maryknoll, NY.

Bremner, L., 2000, 'Reinventing the Johannesburg inner city', Cities 17(3), 185-193. https://doi.org/10.1016/S0264-2751(00)00013-5

Centre on Housing Rights and Evictions (COHRE), 2005, Any room for the poor? Forced evictions in Johannesburg, South Africa, Draft Document for Discussion, Centre on Housing Rights and Evictions, Johannesburg.

Crush, J., Frayne, B. \& Pendleton, W., 2012, 'The crisis of food insecurity in African cities', Journal of Hunger \& Environmental Nutrition 7(2-3), 271-292, https://doi. org/10.1080/19320248.2012.702448

De Gruchy, J.W., 1986, Theology and ministry in context and crisis, Eerdmans, Grand Rapids, MI.

Door of Hope, viewed 30 April 2018, from http://doorofhope.co.za/our-work.

Door of Hope stories, viewed 30 April 2018, from http://doorofhope.co.za/ stories/.

Flett, J.G., 2014, 'A theology of missio Dei', Theology in Scotland 21(1), 69-78.

Goebel, A., Dodson, B. \& Hill, T., 2010, 'Urban advantage or urban penalty? A case study of female-headed households in a South African city', Health \& Place 16(3), 573-580. https://doi.org/10.1016/j.healthplace.2010.01.002

Guder, D.L., 1998, Missional church: A vision for the sending of the church in North America, Eerdmans, Grand Rapids, MI.

Illegal immigrants in Johannesburg, viewed 02 May 2018, from http://702.co.za/ articles/277171/mayor-herman-mashaba-to-approach-the-courts-to-deportundocumented-immigrants. 
Kritzinger, J.N.J., 2013, Integrated theological praxis, 'Capstone' module, University of South Africa, Pretoria.

Mangayi, L., 2016, 'Mission in an African city: Discovering the township church as an asset towards local economic development in Tshwane', PhD thesis, Department of Christian Spirituality, Church History and Missiology, University of South Africa, Pretoria, viewed 18 September 2018, from http://hdl.handle. net $/ 10500 / 22674$.

Marshall, K. \& Van Saneen, M., 2007, Development and faith: When mind, heart, and soul work together, The World Bank, Washington, DC.

Matshedisho, R., 2015, 'Homelessness in Berea Park, Hillbrow', in S. Vertovec (ed.) Diversities old and new: Migration and socio-spatial patterns in New York, Singapore and Johannesburg, pp. 144-155, Palgrave Macmillan, London.

Matshedisho, R. \& Wafer, A., 2015, 'Hillbrow, Johannesburg', in S. Vertovec (ed.), Diversities old and new: Migration and socio-spatial patterns in New York, Singapore and Johannesburg, pp. 67-83, Palgrave Macmillan, London.

Morris, A., 1996, Bleakness and light: Inner city transition in Hillbrow, Johannesburg, Witwatersrand University Press, Johannesburg.

Morris, A., 1999, 'Race relations and racism in a racially diverse inner city neighbourhood: A case study of Hillbrow, Johannesburg', Journal of Southern African Studies 25(4), 667-694, https://doi.org/10.1080/0305707 99108524
Mosselson, A., 2017, 'It's not a place I like, but I can live with it: Ambiguous experiences of living in state-subsidised rental housing in inner-city Johannesburg', Transformation: Critical Perspectives on Southern Africa 93, 142-169. https://doi. org/10.1353/trn.2017.0006

Noble, M., Wright, G. \& Cluver, L., 2006, 'Developing a child-focused and multidimensional model of child poverty for South Africa', Journal of Children and Poverty 12(1), 39-53, https://doi.org/10.1080/10796120500502136

Roozen, D.A., McKinney, W. \& Caroll, J.W., 1984, Varieties of religious presence, The Pilgrim Press, New York.

Swart, I., 2010, 'Churches as stock of social capital for promoting social development in Western Cape communities', in I. Swart, H. Rocher, S. Green \& J. Erasmus (eds.), Religion and social development in post-apartheid South Africa: Perspectives for critical engagement, pp. 325-351, Sun Press, Stellenbosch.

Swart, I., Rocher, H., Green, S. \& Erasmus, J. (eds.), 2010, Religion and socia development in post-apartheid South Africa: Perspectives for critical engagement, Sun Press, Stellenbosch.

Swart, I., 2012, 'Transforming social welfare? The religious discourse on social development in post-apartheid South Africa', in I. Swart, A. Gouws \& P. Pettersson (eds.), Welfare, religion and gender in post-apartheid South Africa: Constructing a south-north dialogue, pp. 65-94, Sun Media, Stellenbosch.

Ter Haar, G. (ed.), 2011, Religion and development: Ways of transforming the world, 93(2017), Hurst \& Company, London. 